\title{
Natural Infection of Wild Grass Species with Rice Blast Fungus Suggested by DNA Fingerprinting*
}

\author{
Motoaki KuSABA**, Le Dinh DON**, Alfredo S. URASHIMA**, Yukiko ETO**, \\ Yukio TOSA**, Hitoshi NAKAYASHIKI**, Masaaki YAMAMOTO** \\ and Shigeyuki MAYAMA**
}

Key words : DNA fingerprint, MAGGY, Magnaporthe grisea, retrotransposon, weed grass host.

Blast disease of rice (Oryza sativa) is a serious disease in many rice growing countries, caused by Pyricularia oryzae Cavara $\left[=P\right.$. grisea (Cooke) Sacc ${ }^{12)}$ teleomorph: Magnaporthe grisea (Hebert) Barr]. The fungus has been isolated from several other gramineous plant species coexistent with rice in the agroecosystem ${ }^{6}$. Whether these plants serve as collateral hosts for the rice pathogen is an important question for blast management.

Recent molecular genetic analyses have suggested that Pyricularia isolates from different hosts are genetically distinct ${ }^{13)}$ and that pathogen populations infecting hosts other than rice do not provide inocula against rice crops in the field ${ }^{3}$. However, the results are contradictory in several pathogenicity studies of Pyricularia isolates ${ }^{2,5,9,10,17)}$. Results from artificial inoculation tests showed that numerous gramineous species commonly found in rice-growing areas were susceptible to the rice blast fungus ${ }^{2}$. Furthermore, several researchers have reported cross-pathogenicity of Pyricularia species isolated from rice and other hosts ${ }^{5,9,10,17)}$. These observations suggest that some grass species could be reservoirs of inoculum for infection of rice. Kato and Yamaguchi ${ }^{5)}$ found in cross-inoculation tests that field isolates from Italian ryegrass (Lolium multiflorum), sweet vernalgrass (Anthoxanthum odoratum) and reed canarygrass (Phalaris arundinacea) were pathogenic on rice and vice versa. The isolates from these host species also parasitized several other grass species that were susceptible to rice isolates. Since the host range of these isolates was very similar to that of rice isolates, Kato and Yamaguchi ${ }^{5)}$ proposed that these weed isolates were intrinsically rice blast isolates. In addition to these isolates, isolates from tall fescue (Festuca arundinacea) were pathogenic on rice and also were suggested to be rice blast isolates ${ }^{17)}$.

MAGGY is an LTR-retrotransposon ${ }^{4)}$ present in a high copy number in isolates from rice, foxtail millet (Setaria italica) and green bristlegrass $(S \text {. viridis })^{15)}$. We also found multiple copies of MAGGY in isolates from Italian ryegrass, sweet vernalgrass, reed canarygrass and tall fescue. Dispersed repeated DNA sequences such as MAGGY have been widely used for fingerprinting and phylogenetic analyses of Pyricularia isolates ${ }^{7,8,16)}$. In these studies, diverse isolates population could be differentiated into lineages, or groups of isolates with similar DNA banding patterns, which were inferred to be related by their descent from a common ancestor. In the present study, genetic relationships between rice isolates and the isolates from the four weed grasses were examined by DNA fingerprinting analysis using MAGGY as a probe to obtain further evidence that grass weeds can be naturally infected with the rice blast fungus.

A total of 18 isolates, comprised of 11 isolates from rice (including one isolate from $O$. longistaminata) and seven Japanese isolates from five weed grass species were used in this study (Table 1). The pathogenicity of these isolates on rice is presented in Table 1. All isolates were pathogenic on rice, except for an isolate from buffel grass (Cenchrus ciliaris) (Kato et al., in preparation). The buffel grass isolate, which also has multiple copies of MAGGY, was nonpathogenic on rice. These isolates were maintained on barley grains under dry conditions at $5^{\circ} \mathrm{C}$ for long-term storage. For DNA extraction, fungal isolates were grown in $50 \mathrm{ml}$ potato dextrose broth in $100 \mathrm{ml}$ Erlenmeyer flasks at $23^{\circ} \mathrm{C}$ for 4 days. Total DNA of each isolate was prepared from the resulting mycelia by the method of Adachi et al. ${ }^{1}$, digested with Bam HI (Toyobo), and fractionated on a $0.8 \%$ agarose gel (GP-36: Nacalai tesque) in $0.5 \times \mathrm{TBE}$ buffer. The fractionated DNA was transferred to nylon membranes (MagnaGraph, MSI) and fixed by UV irradiation according to the manufacturer's instructions. The $0.56 \mathrm{~kb}$ SalI-Bam HI fragment (SB) isolated from a MAGGY clone pMGY23 ${ }^{15}$ was used as a probe for detecting DNA fingerprints. The DNA probe was labeled with biotin using NEBlot-Photope Kit (New England). Hybridization was carried out in $6 \times \mathrm{SSC}$ containing $5 \times$ Denhardt's solution, $0.5 \%$ sodium dodecyl sulfate and $100 \mu \mathrm{g}$ of sonicated salmon sperm DNA

* This work was supported by grants-in-aid from the Ministry of Education, Science, Sports and Culture of Japan.

** Laboratory of Plant Pathology, Faculty of Agriculture, Kobe University, Rokkodai, Nada-ku, Kobe 657-8501, Japan 神戸大学農学部植物病理学研究室 
Table 1. Pyricularia isolates used in this study

\begin{tabular}{|c|c|c|c|c|c|}
\hline Host & Isolate $^{a)}$ & \multicolumn{2}{|c|}{ Locality ${ }^{b)}$} & Collector & $\begin{array}{l}\text { Pathogenicity }{ }^{\text {c) }} \\
\text { on rice }\end{array}$ \\
\hline \multicolumn{6}{|l|}{ Oryza sativa $\mathrm{L}$. } \\
\hline \multirow[t]{10}{*}{ (rice) } & $0903-4[003]$ & Tochigi & Japan & M. Yamada & + \\
\hline & $2012-1[007]$ & Ishikawa & Japan & M. Yamada & + \\
\hline & $88 \mathrm{~A}[433]$ & Ibaraki & Japan & M. Yamada & + \\
\hline & IN77-32-1-1 & Mysore & India & H. Kato & + \\
\hline & UN-05-1 & Yunnan & China & M. Iwano & + \\
\hline & ISH-5-1 & Yunnan & China & M. Iwano & + \\
\hline & CHNOS59-6-11 & Yunnan & China & N. Hayashi & + \\
\hline & CHNOS60-8-1 & Yunnan & China & N. Hayashi & + \\
\hline & Br11 & Paulo Frontin & Brazil & S. Igarashi & + \\
\hline & $\mathrm{CD} 276$ & - & Cote d'lvoire & J. M. Bidaux & + \\
\hline \multicolumn{6}{|c|}{ Oryza longistaminata A. Chev. et Roehr. } \\
\hline & $\mathrm{CD} 262$ & - & Cote d'lvoire & J. M. Bidaux & + \\
\hline \multicolumn{6}{|c|}{ Phalaris arundinacea $\mathrm{L}}$. \\
\hline \multirow[t]{2}{*}{ (reed canarygrass) } & NI901 & Tochigi & Japan & N. Nishihara & + \\
\hline & NI921 & Tochigi & Japan & N. Nishihara & + \\
\hline \multicolumn{6}{|c|}{ Anthoxanthum odoratum L. } \\
\hline (sweet vernalgrass) & NI904 & Tochigi & Japan & N. Nishihara & + \\
\hline \multicolumn{6}{|c|}{ Festuca arundinacea Schreb. } \\
\hline (tall fescue) & NI899 & Tochigi & Japan & N. Nishihara & + \\
\hline \multicolumn{6}{|c|}{ Lolium multiflorum Lam. } \\
\hline \multirow[t]{2}{*}{ (Italian ryegrass) } & GFIT1-1 & Gifu & Japan & H. Kato & + \\
\hline & GFIT6-1 & Gifu & Japan & H. Kato & + \\
\hline $\begin{array}{l}\text { Cenchrus ciliaris L. } \\
\text { (buffel grass) }\end{array}$ & NI981 & Kumamoto & Japan & N. Nishihara & - \\
\hline
\end{tabular}

a) Race numbers are shown in square brackets.

b) -, unknown.

c) + , pathogenic; - , nonpathogenic.

\section{8}

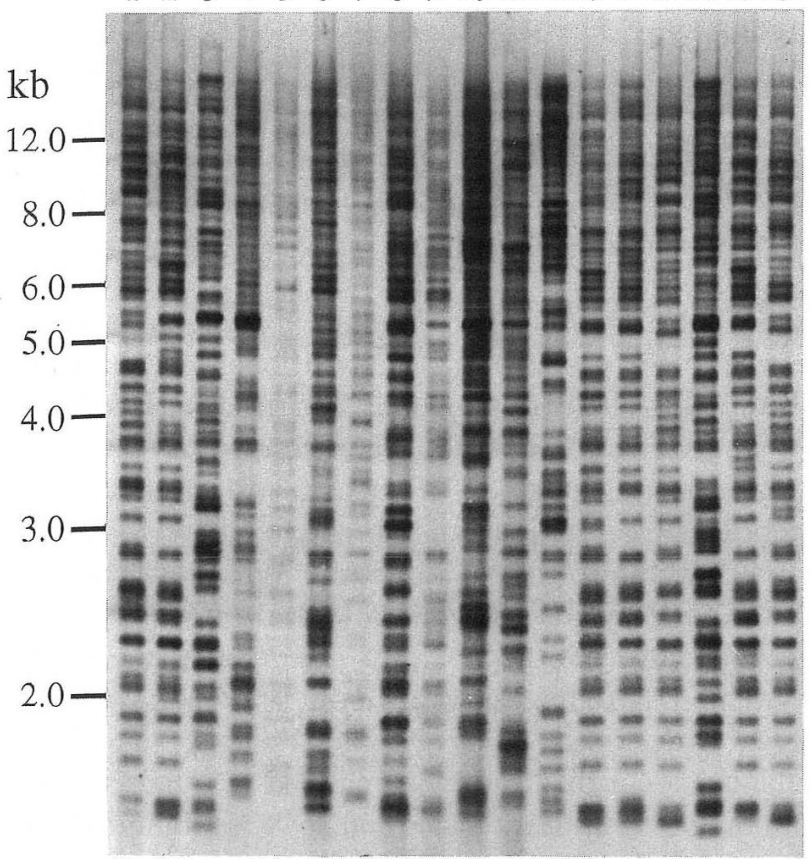

per $\mathrm{ml}$ at $68^{\circ} \mathrm{C}$. Hybridized membranes were washed at $68^{\circ} \mathrm{C}$, with the final wash in $0.1 \times \mathrm{SSC}$ containing $0.1 \%$ sodium dodecyl sulfate. Detection of DNA blots was
Fig. 1. DNA fingerprints of 18 Pyricularia isolates from rice and five grass weed species. The lanes contained DNA from: 1, 88A ; 2, 0903-4 ; 3, 2012-1 ; 4, UN-05-1 ; 5, ISH-5-1 ; 6, CHNOS59-6-11; 7, CHNOS60-8-1; 8, Br11 ; 9, CD262 ; 10, CD276 ; 11, IN77-32-1-1 ; 12, NI981; 13, NI901 ; 14, NI921 ; 15, NI904 ; 16, NI899 ; 17, GFIT1-1 ; 18, GFIT6-1. The sizes of DNA (in kilobases) are indicated on the left.

performed by using the Phototope-Star Detection Subkit (New England).

The resulting DNA fingerprints are shown in Fig. 1. 


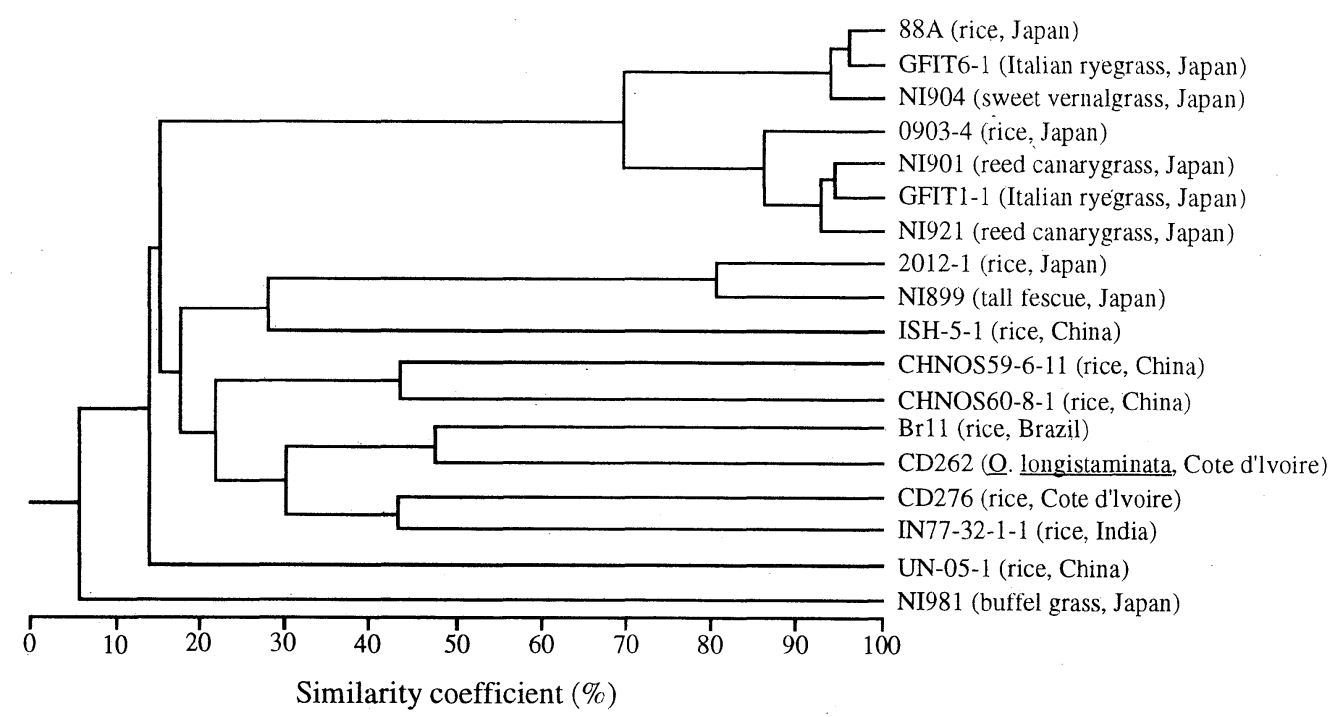

Fig. 2. Dendrogram showing the level of genetic relatedness of 18 Pyricularia isolates from rice and five grass weed species. Hosts and localities of isolates are shown in parentheses.

Hybridization fragments larger than $5 \mathrm{~kb}$ in size were excluded from the evaluation for polymorphisms of the fingerprints. Consequently, the hybridization produced 154 different resolvable fragments (smaller than $5 \mathrm{~kb}$ in size) in the isolates tested. The 18 isolates were classified into distinctive fingerprint patterns. A cluster analysis of the fingerprint data was used to calculate the similarity coefficients $^{11)}$ between isolates, and to construct a dendrogram using UPGMA ${ }^{14}$ (Fig. 2).

In the dendrogram, all rice isolates were grouped into a single cluster, but with a very low similarity level (14\%). Japanese rice isolates 88A and 0903-4 were relatively close to each other with $69 \%$ similarity. However, the other Japanese rice isolate 2012-1 and eight isolates from the other four countries were classified into groups different from the two Japanese isolates with lower than $17 \%$ similarities. Such low levels of similarity suggested genetic diversification within the rice isolates populations. One isolate from buffel grass, which is not pathogenic to rice, was most distant from all the other isolates with only a $5 \%$ similarity in the dendrogram. On the other hands, six Japanese isolates from the four weed grass species were closely related to Japanese rice isolates with higher than $80 \%$ similarity levels. These weed isolates were divided into three groups, each of which was close to one of the three Japanese rice isolates.

Kato et al. (in preparation) have already confirmed that the same isolates from the four weeds used in this study were pathogenic not only on rice but also on other host plants which were susceptible to the rice blast fungus. Thus, these pathogenicity tests suggest, as did previous field studies ${ }^{2,5,9,10,17)}$, that the isolates from these four weed species are the rice pathogen with the ability to infect these grass weeds.

Such weeds may act as collateral hosts of the rice blast fungus in the agroecosystem. On the other hand,
Borromeo et al. ${ }^{3)}$ reported that populations of weed isolates do not provide inoculum to rice in the field in the Philippines. They examined genetic relationships among isolates from rice and 16 weed grass species in the Philippines based on RFLP analyses using 10 single-copy DNA probes. The dendrogram constructed from the RFLP data showed that the rice isolates were distinct from those on other host species. However, their isolates from weed grass hosts did not include any from Lolium, Anthoxanthum, Phalaris or Festuca. Thus, some weed species may serve as collateral hosts for the rice pathogen, whereas others may not.

We are grateful to National Agriculture Research Center, for continuous supports to this study, and Mr. M. Okuda, Chugoku National Agricultural Experiment Station, for providing the computer program software used to construct the dendrogram. We express our special thanks to Dr. H. Kato, the former professor of Kobe University, for valuable suggestions and comments. This work was partly supported by grants-in-aid from the Ministry of Education, Science, Sports and Culture of Japan.

\section{Literature cited}

1. Adachi, Y., Watanabe, H., Tanabe, K., Doke, N., Nishimura, S. and Tsuge, T. (1993). Nuclear ribosomal DNA as a probe for genetic variability in the Japanese pear pathotype of Alternaria alternata. Appl. Environ. Microbiol. $59:$ 3197-3205.

2. Asuyama, H. (1963). In The Rice Blast Disease: Proceedings of a Symposium, IRRI, The Johns Hopkins University Press, Baltimore, Maryland, pp. 9-22.

3. Borromeo, E.S., Nelson, R.J., Bonman, J.M. and Leung, H. (1993). Genetic differentiation among isolates of Pyricularia infecting rice and weed hosts. Phytopathology $83:$ 393-399.

4. Farman, M.L., Tosa, Y., Nitta, N. and Leong, S.A. 
(1996). MAGGY, a retrotransposon in the genome of the rice blast fungus Magnaporthe grisea. Mol. Gen. Genet. 25 : 665-674.

5. Kato, H. and Yamaguchi, T. (1980). Host ranges and interrelations of Pyricularia species from various cereals and grasses. Proc. Kanto-Tosan Plant. Prot. Soc. 27 : $14-15$.

6. Kozaka, T. and Kato, H. (1980). In Rice Blast Disease and Breeding of Resistant cultivars (Yamasaki, Y. and Kozaka, T. eds.), Hakuyusha, Tokyo, pp. 47-80 (in Japanese).

7. Levy, M., Correa-Victoria, F.J., Zeigler, R.S., Xu, S. and Hamer, J.E. (1993). Genetic diversity of the rice blast fungus in a disease nursery in Colombia. Phytopathology 83 : 1427-1433.

8. Levy, M., Romao, J., Marchetti, M.A. and Hamer, J.E. (1991). DNA fingerprinting with a dispersed repeated sequence resolves pathotype diversity in the rice blast fungus. Plant Cell 3 : 95-102.

9. Mackill, A.O. and Bonman, J.M. (1986). New hosts of Pyricularia oryzae. Plant Dis. 70 : 125-127.

10. Namai, T., Nukina, M., Saigusa, M. and Togashi, J. (1996). Blast disease occurred on wild rice, Zizania palustris L. caused by Pyricularia sp. Ann. Phytopathol. Soc. Jpn. $62:$ 247-253.

11. Nei, M. and Li, W.-H. (1979). Mathematical model for studying genetic variation in terms of restriction endonucleases. Proc. Natl. Acad. Sci. USA 76 : 5269-5273.

12. Rossman, A.Y., Howard, R.J. and Valent, B. (1990). Pyricularia grisea, the correct name for the rice blast disease fungus. Mycologia 82 : 509-512.

13. Shull, V. and Hamer, J.E. (1994). In Rice Blast Disease (Zeigler, R. et al. eds.), CABI, London, pp. 65-86.

14. Sneath, P.H.A. and Sokal, R.R. (1973). Numerical
Taxonomy: The Principles and Practice of Numerical Classification, Freeman, W.H. \& Co., San Francisco, California.

15. Tosa, Y., Nakayashiki, H., Hyodo, H., Mayama, S., Kato, H. and Leong, S.A. (1995). Distribution of retrotransposon MAGGY in Pyricularia species. Ann. Phytopathol. Soc. Jpn. 61 : 549-554.

16. Xia, J.Q., Correll, J.C., Lee, F.N., Marchetti, M.A. and Rhoads, D.D. (1993). DNA fingerprinting to examine microgeographic variation in the Magnaporthe grisea (Pyricularia grisea) population in two rice fields in Arkansas. Phytopathology 83 : 1029-1035.

17. Yaegashi, H. (1981). Studies on the perfect stage of Pyricularia species. Bull. Tohoku Natl. Agric. Exp. Stn. $63: 49-125$ (in Japanese).

\section{和 文 摘 要}

草場基章・Le Dinh DoN - Alfredo S. URASHIMA ・ 衛籐由希 子・土佐幸雄・中屋敷均・山本正晃・眞山滋志：DNAフィンガ ープリンティング分析により示唆されたイネいもち病菌の野生 イネ科植物への自然感染

MAGGYをプローブとしたDNAフィンガープリント分析に より，世界各地から採集したイネいもち病菌と日本産野生イネ 科植物いもち病菌との遺伝的類縁関係を調査した。供試菌から 得られたDNAフィンガープリントに基づきクラスター分析を 行ったところ, 日本産と外国産イネ菌の類縁性は, $27 \%$ 以下であ った。一方，日本産ネズミムギ，ハルガヤ，クサヨシ，オニノウ シノケグサ各菌は日本産イネ菌に対して $80 \%$ 以上の高い類縁性 を示した。以上の結果から，これら日本産の野生イネ科植物の菌 はイネ菌がこれら植物に感染したものであると推定される。

(Received November 25,1997; Accepted December 18,1997) 